\title{
A Research on Normalized Construction of Logistics Information Platform
}

\author{
Jie ZHU1 ${ }^{1}$, Bin-Bin FU², Heng-Liang TANG ${ }^{3}$, Chun-Lin ZHANG ${ }^{4}$ \\ 1,2,3,4 School of Information, Beijing Wuzi University, Beijing 101149, China
}

Keywords: Logistics informatization, Logistics information platform, Normalized construction.

\begin{abstract}
The logistics industry in China has developed into a unique pattern. Logistics informatization is one of the important parts of modern logistics, which distinguishes with the traditional logistics. More and more urgent demands for logistics information generates with the development of social logistics. The key problem that needs to be solved in modern logistics is how to analyze and extract the useful information from a great deal of information. This paper mainly analyzes the potential users of logistics information platform, and proposes a novel design pattern and operation procedure for modern logistics information platform, which promotes the development of modern logistics to some extent.
\end{abstract}

\section{Introduction}

With the development of the internetwork and information technology, the construction of information platform becomes an important trend for modern logistics. Due to the large cost of construction, a single enterprise can't afford such great expense. It is urgent to build a logistics information platform to provide public services. The platform can share information and integrate resources among logistics enterprises, which can also change the traditional distributed operation pattern, and play the overall advantages of the logistics industry.

The existing information platform is in chaos, and is mostly build by a single enterprise or a few business enterprises that in cooperative relationship. It is difficult to be generalized due to the limited capital, technology and information sharing, so the information platform can't show the superiority or function very well. An effective scheme should be led by the government ${ }^{[1]}$, and supported by the relevant enterprises, to form a public logistics information service platform based on standardized technology which can share the information and management.

A whole systematized logistics information platform should own the distinctive features as follows: ${ }^{[2]}$

(1) Integration. A new system is formed by integrating two or more different subsystems which have a certain structure and specific functions. Every subsystem cooperates with each other to perform the maximum utility. (2) Hierarchy. People will have thorough understanding of macro system and internal system through analyzing each hierarchy. (3) Purpose. In order to achieve different purposes, the composition of each subsystem can present a different structure. (4) Relevancy (5) Dynamics. (6) Environment adaptability. It can provide the service for the development of market.

A good logistics information platform can not only integrate the material flow and the information flow together, but also play key role in the aspects of optimizing resources allocation, integrating logistics resources and normalizing the market management ${ }^{[3]}$. To form a good logistics information platform can promote the cooperation between enterprises and integrate the social resources, and also give full play to the government macroeconomic regulation and control ability of the market.

Logistics information platform can gradually establish in the region, province and nation levels.

\section{The standard requirements of logistics information platform}

\section{The demand of logistics enterprises}

Commodities experience multiple links in the circulation process, and logistics companies have different demand for the logistics system as follows. 1) The general business operation pattern and 
normalized process management standards are needed for enterprises, to realize the standard information exchange and eliminate the communication disorders. 2) The Information coordination between each link of logistics is needed. In the global logistics links, it is difficult to trace a commodity from the origin to the terminal for any logistics companies, which restricts the development of electronic commerce. 3) Enterprise need share The common information need to be shared among logistics enterprises, and the common information are mainly consist of the development of the logistics infrastructure, the relevant policies and regulations, and so on. 4) Enterprises need the trusteeship of application services. Most enterprises in the logistics links are small-scale, and can't afford the logistics information management system by their own. 5) With the development of logistics information platform, the intelligent business and financial services are needed to expand new functions to meet the needs for a certain custom.

The logistics enterprises can be categorized into three parts of transport, storage and comprehensive service, and every owns different needs for the logistics information platform.

Transportation logistics enterprises mainly include three areas: transportation by sea, land, and air. They need the timely access to the information about transport capacity, delivery time, real time supervision and so on.

Warehousing logistics enterprise mainly includes logistics park, warehouses, docks, etc. Requirements lists as follows: monitor the management of goods, vehicles and outbound, tracking vehicles according to the need for real-time, tracking cargo information and collecting statistics, releasing information to the platform. People can obtain warehouse usage and manage enterprise accounts basing on the requirements.

Integrated service-oriented logistics enterprises mainly include international trading company, information service platform, etc. Its requirements including information query, monitoring and information release, etc.

\section{Administrative department needs}

Transportation management department is responsible for monitoring and regulating transport in the process of goods transport .Therefore, logistics information platform should meet the following requirements: 1) government information release 2) e-government information service 3) data sharing 4) decision analysis 5) understand the overall situation of logistics development 6) data processing .

Trade management department is mainly responsible for supervise logistics trading and collecting data in order to provide overall planning, macroeconomic regulation and control and policy support for logistics industry development Logistics information platform should meet the following requirements: 1) the new policy and development planning 2) data processing 3) the whole information of logistics industry development, including the overall operation of the industry; the distribution, scale, infrastructure construction, main problems of logistics enterprises, etc.

\section{Customers' needs}

Platform customers mainly include three classes: logistics user enterprise, logistics service enterprises, logistics equipment enterprise ${ }^{[4]}$.

1) Logistics user enterprise need platform to provide logistics services and solutions to ensure the cargo and capital security 2) Logistics service enterprise can provide logistics service to upstream and downstream customers through the information platform to promote growth of benefit.3) Logistics equipment enterprises can display and provide detailed information and product prices for all kinds of storage and transportation equipment, packaging, processing equipment, loading and unloading handling equipment and information technology equipment through the platform. We can realize the online trade and satisfy both sides of supply and demand.

\section{The normalization function of logistics information platform}

The logistics information platform mainly aims at providing information supporting for companies' decisions making to satisfy company's demand for information through collecting information. (transportation information, restoration information, logistic information, etc.) Meanwhile, it updates and counts the information, which facilitates government monitoring market 
and managing the industry.

\section{The choice for function module}

Based on the texts and logistic information platform we have, and proved by survey and query, the corporations that runs for more than 5 years accounts for more than $45 \%$, and $34 \%$ for those 3 to 5 year-old companies. The majority of companies have relatively long running time. Besides, the using rate of logistic information platform is low, and the main reason for that is that they don't know whether the goods sources are trust worthy or the corporation has a good reputation. ${ }^{[5]}$

The survey result is arranged in the following table:

Table 3.1 The statistic survey result table

\begin{tabular}{|c|c|c|c|c|}
\hline item & $\begin{array}{c}\text { Very } \\
\text { important }\end{array}$ & important & $\begin{array}{c}\text { Less } \\
\text { important }\end{array}$ & unimportant \\
\hline $\begin{array}{c}\text { Transportation expenses } \\
\text { information }\end{array}$ & $71.3 \%$ & $23.4 \%$ & $4.3 \%$ & $1.0 \%$ \\
\hline Restoration information & $53.4 \%$ & $32.5 \%$ & $12.3 \%$ & $1.8 \%$ \\
\hline Vehicle information & $63.2 \%$ & $28.5 \%$ & $8.3 \%$ & 0 \\
\hline $\begin{array}{l}\text { Goods resources } \\
\text { information }\end{array}$ & $55.3 \%$ & $37.4 \%$ & $4.2 \%$ & $3.1 \%$ \\
\hline Contract management & $35.8 \%$ & $43.2 \%$ & $14.1 \%$ & $6.9 \%$ \\
\hline Order management & $35.2 \%$ & $52.1 \%$ & $11.2 \%$ & $2.5 \%$ \\
\hline $\begin{array}{l}\text { Logistic function } \\
\text { management }\end{array}$ & $14.5 \%$ & $56.3 \%$ & $23.6 \%$ & $5.6 \%$ \\
\hline $\begin{array}{c}\text { Clients relation } \\
\text { management }\end{array}$ & $39.2 \%$ & $56.4 \%$ & $4.4 \%$ & 0 \\
\hline $\begin{array}{c}\text { Electronic invoice } \\
\text { transmission }\end{array}$ & $26.3 \%$ & $55.4 \%$ & $13.7 \%$ & $4.6 \%$ \\
\hline $\begin{array}{l}\text { Enterprise qualification } \\
\text { certification }\end{array}$ & $37.8 \%$ & $36.9 \%$ & $22.4 \%$ & $2.9 \%$ \\
\hline Trade information & $34.2 \%$ & $45.1 \%$ & $17.9 \%$ & $2.8 \%$ \\
\hline Logistic plan design & $21.2 \%$ & $46.3 \%$ & $23.9 \%$ & $8.6 \%$ \\
\hline $\begin{array}{c}\text { The location choice for } \\
\text { facilities }\end{array}$ & $16.8 \%$ & $42.3 \%$ & $32.6 \%$ & $8.3 \%$ \\
\hline Stock management & $13.5 \%$ & $36.2 \%$ & $32.4 \%$ & $17.9 \%$ \\
\hline Car dispatch & $31.1 \%$ & $43.7 \%$ & $24.0 \%$ & $1.2 \%$ \\
\hline Intelligential dispatching & $20.9 \%$ & $38.4 \%$ & $24.6 \%$ & $16.1 \%$ \\
\hline $\begin{array}{l}\text { Logistic demand } \\
\text { information }\end{array}$ & $53.6 \%$ & $32.2 \%$ & $14.2 \%$ & 0 \\
\hline $\begin{array}{l}\text { Logistic service } \\
\text { information }\end{array}$ & $15.4 \%$ & $43.9 \%$ & $24.6 \%$ & $16.1 \%$ \\
\hline $\begin{array}{l}\text { Weather and road } \\
\text { condition information }\end{array}$ & $18.3 \%$ & $42.8 \%$ & $23.7 \%$ & $15.2 \%$ \\
\hline
\end{tabular}

Data resource: research on public logistic information platform's function system and structure. Kong Zhuo,SouthWest Jiaotong University,2011.5

As the table above manifest, above $90 \%$ people think that transportation fees information is very important. The reason is that transportation weighs a lot in the total cost. So the scheming 
transportation route and learning vehicles' loading are the information that is welcomed by the logistic enterprise. Up to 92\%corporations believe the goods resources information is the most important. They are all hoping to get specific information through the logistic information platform.

\section{The construction of function module}

The main function is as follows:

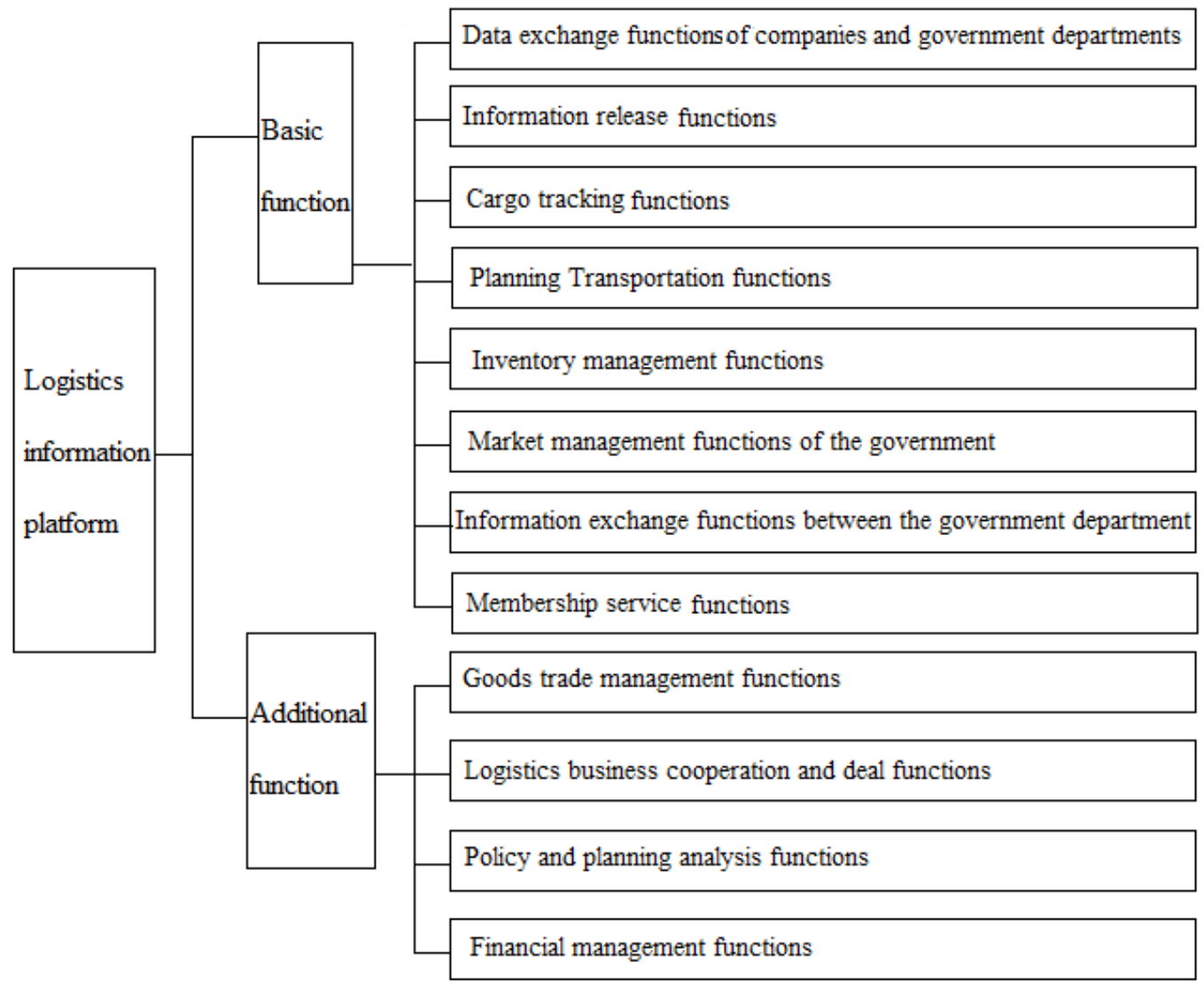

Figures 3.1 The function structure of logistic information service platform

The main function introduction:

1. The information query and release function. This function could be realized by the form of the internet. The enterprises only need to log in the internet website to get access to the platform, and they can get the related information ${ }^{[6]}$. This kind of information mainly includes transportation price, the vehicle dispatch, goods resources and transport capacity, the train numbers information, news and notice, political orientation, occupation training, policy regulations, etc.

2. Data exchanging function. It renders the data exchanging support for the third party. The logistic information platform's core function lies in the electronic information's communication, translation and transfer, which includes the information exchange and warrant.

3. Cargo tracking, through a variety of information gathering techniques, the use of GPS / GIS system to obtain information on the status and location of goods. The status and location data upload stored in the data base, the user can get the tracking information via Web sites or information center.

4. Transportation planning functions of the transport resource availability information businesses, logistics centers and consumer shopping information integration to achieve optimal distribution, in order to reduce distribution costs. Through intelligent distribution can solve the following problems: including distribution model selection, route selection, picking the order, the customer requested delivery time.

5. Inventory management functions, customer demand information obtained through the information platform, and rapid response to meet quality of service assurance while reducing costs. 
After a lot of data collection and analysis to calculate optimal inventory levels, current typical problems to be solved are: the total production of the next cycle, safety stock, optimal fill volume.

6. The government market management functions through a network of logistics market data in real-time monitoring and logistics industry, to provide information support for policy to regulate the market. At the same time through the platform of the new government policy announcements and publicity.

7. Exchange of information between government departments, through information sharing between government departments to make information to maximize value, not only improve the efficiency of government departments, but also to our smooth transition to a more advanced stage from the initial stage of e-government ${ }^{[7]}$.

\section{Logistics Information Platform operational processes}

Processes mainly related to logistics customers, logistics information platform, logistics service centers, service providers and government agencies. Its implementation process:

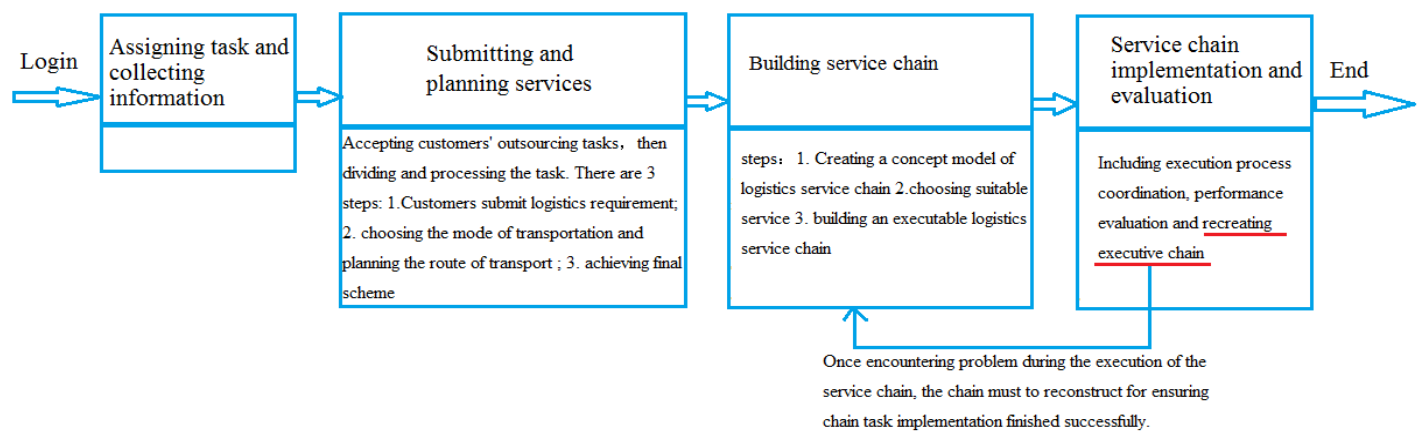

Figures 3.2 Logistics Information Platform operational processes

\section{Conclusion}

Modern logistics information platform greatly supports the development of modern logistics enterprises ${ }^{[8]}$, and can integrate logistics resources, improve the logistics service quality and decrease logistics costs by applying high-tech information technology and electronic commerce and integrating logistics and information flow. Meanwhile, the statistical analysis of logistics data provides first-hand information about the industry to the government, which contributing to the development of government policy formulation in order to achieve standardized management about the modern market. Through the investigation and the demand analysis of logistics information platform, a novel design pattern and operation procedure for modern logistics information platform are presented in this paper, which promotes the development of modern logistics to some extent. Due to the construction of modern logistics information platform is just in the initial stage in China, there are less successful cases worthy to be referenced. So there are many topics need to be further studied in the future.

\section{Acknowledgement}

This research was supported by the Beijing key intelligent logistics system laboratory.

\section{References}

[1] Fang Fengping, Zeng Yanying. Urban logistics information platform for planning and design empirical analysis [J] Communication Enterprise Management, 2010 (1): 56-57.

[2] Tang Yinying, Du Wenhong, Qian Jian. Explore the construction of public logistics information platform [J]. Railway Transport and Economy, 2009 (5): 61-67. 
[3] Chen Jijun, Gan Shiyu, Zhan Fudon. Research on the development prospects for logistics public information platform [J]. Logistics Technology, 2010 (1): 128-131.

[4] Liu Chunyue. Public logistics information platform needs analysis and functional design of the platform [D] Southwest Jiaotong University, 2009 (8): 122-123.

[5] Kong Zhuo. Research on public logistic information platform's function system and structure [D]. Southwest Jiaotong University, 2011.5.

[6]Wang Tao. Building modem logistics application platform based on Web/GPS/GIS/GPRS [J]. Radio Engineering, 2002, 32(2): 48-51.

[7]Zhang Qian, Pan Jianping Platform of public logistic information in Xiamen [J]. Journal of Chang'an University (Social Science Edition), 2006, (4): 95-99.

[8] Zhao Xiaoyun, Wang Yaoqiu. Research on the influence of the regional logistics information platform of regional logistics [J]. Logistics Engineering and Management, 2009, 31 (2):16-19. 